\title{
ADVANCING DOCTRINE THROUGH DEVIL'S ADVOCACY: A RESPONSE TO ALAN O. SYKES
}

\author{
Alberto Alvarez-Jimenez**
}

Alan Sykes' editorial comment, Economic "Necessity" in International Law, provides a multi-layered analysis of the defense of "necessity" in international investment disputes. Sykes' main proposition is that the obligation to compensate investors for government measures prejudicing their investments during economic emergencies mitigates the risk of moral hazard and incentivizes States to "select the least expensive way to protect their interests (the optimal policy instrument)."1 Otherwise, he contends, "actors will take risks that imperil them to an excessive degree if they can save themselves by imposing costs on others."2 Sykes nonetheless argues that payment of the compensation could be deferred in light of the emergency, and not be subject to market interest rates. ${ }^{3}$

He derives his proposal from law-and-economic analysis and in light of the case law generated in particular by arbitrations in claims against Argentina resulting from its 2001 financial crisis. In these cases, Argentina invoked the customary international law of necessity and, in claims by U.S. claimants, it also invoked the emergency clause included in Article XI of the United States-Argentina Bilateral Investment Treaty (BIT):

This Treaty shall not preclude the application by either Party of measures necessary for the maintenance of public order, the fulfillment of its obligations with respect to the maintenance or restoration of international peace or security, or the protection of its own essential security interests. ${ }^{4}$

This comment focuses on that treaty clause.

In recent years, some of this case law has indicated that the successful invocation of emergency clauses precludes violations of the treaty. ${ }^{5}$ Consequently, according to such case law, the State owes no compensation to investors during situations of emergency for damages caused by measures aimed at coping with the crisis. ${ }^{6}$

This case law transfers all of the risks during situations of emergency to investors, while the quite strict approach of the customary rule of necessity embodied in Article 25 of the International Law Commission's

* Senior lecturer, Faculty of Law, University of Waikato, New Zealand. aalvarez@waikato.ac.nz:

Originally published online 23 December 2015.

1 See Alan O. Sykes, Economic "Necessity" in International Law, 109 AJIL 296, 321 - 22 (2015).

2 See id. at 299.

3 See id. at 320 .

${ }^{4}$ Treaty Between the United States of America and the Argentine Republic Concerning the Reciprocal Encouragement and Protection of Investment, Arg.-U.S., Nov. 14, 1991, 31 ILM 124.

5 See Sempra Energy International v. The Argentine Republic, Decision on the Argentine Republic's Application for Annulment of the Award, ICSID Case No. ARB/02/16, para. 200 (June 29, 2010), 49 ILM 1445 (2010).

6 See CMS Gas Transmission Company v. Argentine Republic, Decision of the ad boc Committee on the Application for Annulment of the Argentine Republic, ICSID Case No. ARB/01/8, para. 146 (Sep. 25, 2007), 14 ICSID Rep. 251. 
(ILC) Articles on Responsibility of States for Internationally Wrongful Acts ${ }^{7}$ substantially transfers such risks to States. Basically, there is no risk-sharing mechanism in the case law under these two provisions (Article XI of the BIT and Article 25 of the ILC Articles), and something should be done about it. Thus, as regards general clauses such as Article XI of the United States-Argentina BIT, Sykes rightly advocates for a substantial change in the interpretation of emergency clauses to provide for risk sharing. This comment on the Sykes article is an opportunity to play the devil's advocate in order to advance the debate and identify areas worth exploring further. This contribution has three parts. In the first, the author assesses one of the grounds Sykes relies on in support of his suggestions. The second part explores different dimensions of Sykes' proposals. The third part offers an alternative view that reaches the final outcome that Sykes advocates.

\section{A Missing Piece of the WTO Law Analogy}

Sykes examines several WTO provisions that grant W'TO Members the right to suspend their WTO obligations temporarily in the event of analogous situations, and in particular Articles XII-XV (permitting trade restrictions in the context of balance-of-payments crises) and Article XIX (permitting "safeguard" trade restrictions in the event of a rapid increase in imports causing or threatening to cause serious injury to a domestic industry in an unforeseeable manner). Such WTO law goes in the same direction as Sykes' argument for suspension of obligations under emergency clauses during (but only during) the emergency.

However, Sykes does not address another important WTO provision intimately related to economic crises, which does not support such suspension, namely Paragraph 2 of the GATS Annex on Financial Services. It provides:

Notwithstanding any other provision of the Agreement, a Member shall not be prevented from taking measures for prudential reasons, including for the protection of investors, depositors . . . or to ensure the integrity and stability of the financial system. ${ }^{8}$

Thus, where a State experiences severe economic difficulties and depending on the type of crisis, GATS paragraph 2 may provide a much more important tool for the State to address an economic crisis, given the provision's significance, wide scope, and permanent, not temporary effect, compared to GATT Articles XIIXV. ${ }^{9}$ The GATS paragraph 2 trapdoor shows that W'TO law does not in all cases limit state responses to economic crises or unforeseen events to the merely temporary suspension of WTO obligations. ${ }^{10}$

\footnotetext{
7 See Draft Articles on the Responsibility of States for Internationally Wrongful Acts, Report of the International Law Commission on the work of its fifty-third session, 19 UN GAOR Suppl. No. 10, at 43, UN Doc. A/56/10 (2001), reprinted in [2001] 2 Y.B. Int'l L. Comm'n 26, UN Doc. A/CN.4/SER.A/2001/Add. 1.

${ }^{8}$ For the potential of this provision in dealing with economic crises, see Giorgio Sacerdoti, BIT Protection and Economic Crises: Limits to Their Coverage, the Impact of Multilateral Financial Regulation and the Defense of Necessity, 30 ICSID Review 1, 17 (2013). Sykes only briefly mentions these measures in the BIT context, as opposed to the GATS context. See Sykes, supra note 1, at 303 n. 28.

${ }^{9}$ Contrary to GATT Article XII, which is aimed at economic crises, Article XIX has a much narrower focus: specific domestic industries facing economic hardship. The support the latter provision offers for the temporary suspension of WTO obligations in times of economic collapse is thus more limited.

10 This is not to say that the case law under GATT Article XX and, in particular, the necessity test, cannot be of assistance when assessing the existence of alternative means under ILC Draft Article 25 in investor-State litigation. See Continental Casualty v. Argentine Republic, Award, ICSID Case No. ARB/03/9, paras. 192-200 (Sep. 5, 2008); and Alberto Alvarez-Jimenez, New Approaches to the State of Necessity in Customary International Law: Insights from WTO Law and Foreign Investment Law, 19 AM. REV. INT'L ARB. 463 (2010). When authorized, the suspension of obligation in WTO law exists for the benefit of WTO members only and does not address compensation for private parties.
} 


\section{Moral Hazard in Emergency Clauses: Has Sykes' Proposal an Edge over the Case Law?}

Sykes states that a way to prevent moral hazard as a result of emergency clauses is to require some form of compensation. ${ }^{11}$ An obligation to compensate would incentive States to try to reduce the amount of compensation due by implementing wise economic policies. ${ }^{12}$ The inference, then, is that there is no need to embark on analyses of whether or not a State contributed to a crisis in order for it to successfully invoke emergency clauses. ${ }^{13}$

Sykes' proposal is right in the sense that the requirement of compensation would address the issue of moral hazard. His proposal would have an advantage over the case law if the case law were not acceptably responding to the moral hazard risk. However, some of the case law has been aware of the moral hazard risk, as Sykes himself acknowledges, ${ }^{14}$ and has responded to it by requiring that a State not substantially contribute to the economic emergency in order for it to invoke an emergency clause. The basis for this requirement has been the general principle of international law that "necessity cannot be recognized if a Party to a contract has contributed to it." 15 The introduction of this "no contribution" requirement in the case law is a very important counterbalance to the zero compensation effect of emergency clauses. ${ }^{16}$

In other words, the moral hazard problem in emergency clauses can be dealt with in two ways: with the obligation to compensate, as Sykes recommends, or by interpreting the clause in a way that requires no substantial State contribution, as the El Paso tribunal did in 2011. As it stands, the Sykes proposal does not necessarily have an edge on such case law in addressing the moral hazard problem.

\section{Suspension of Compensation: A Reality Test}

Sykes suggests that the possibility for compensation should be interpreted to exist under emergency clauses, but that the obligation to pay could be deferred by investor-State tribunals until after the economic emergency ends. ${ }^{17}$ The instrument of compensation indeed would help align host States' and investors' interests during economic crises. However, it is important to make clear that suspension of compensation would not always be required. ${ }^{18}$ To illustrate this point, three situations must be distinguished.

First, the case for suspension is very strong when, at the time of the award, the crisis is still ongoing and the government may be concentrating its resources on more pressing needs. Given the time litigation usually takes, this situation would exist only in the event of protracted crises, exceptional but possible. The Great Recession illustrates that protracted economic crises do exist, so there is value in Sykes' proposition, but its value is limited where economic crises are shorter in duration. The second situation is when the award is rendered shortly after the economic calamity has ended. This would include borderline cases, but tribunals'

11 See Sykes, supra note 1, at 321.

12 See id.

13 See id. at 318 .

14 See id. at 317.

15 See El Paso Energy International Company v. The Argentine Republic, Award, ICSID Case No. ARB/03/15, para. 624 (Oct. 31 , 2011). The Annulment Committee rejected an application for annulment. See El Paso Energy International Company and the Argentine Republic, Decision of the ad hoc Committee on the Application for Annulment of the Argentine Republic, ICSID Case No. ARB/03/15, (Sep. 22, 2014), esp. on this point at para. 254.

16 An analysis of whether the requirement should be interpreted strictly or flexibly in light of particular facts is an issue that deserves further elaboration.

17 See Sykes, supra note 1, at 320.

${ }^{18}$ Suspension of compensation may consist in delaying payment of the damages awarded from the date of breach until a specific date. Interest rates lower than market rates would also be included until such a date. 
discretion to suspend compensation would be important for the benefit of host States. Finally, in a third situation, the case for suspension would be very weak when the award is issued several years after the crisis had ended.

On a practical note, the suspension-of-compensation proposal must take into account that, as the Argentine saga evidences, there is a de facto suspension already in place. Take, for instance, the length of the litigation just for the arbitration proceedings in some awards from the Argentine saga, in which the given emergency clause or the customary rule of necessity has been invoked and compensation to investors recognized. The proceedings in CMS v. Argentina took 3 years and 9 months, ${ }^{19}$ those in Total $v$. Argentina 9 years and 6 months, ${ }^{20}$ and those in Continental v. Argentina 5 years and 7 months. ${ }^{21}$ The approximate average of these proceedings is 6.5 years. So, if the Argentina proceedings serve as a proxy for the length of time required for litigation prompted by economic collapses, the suspension of compensation would be an important tool when an economic crisis lasts more than seven years. This de facto suspension is extended when the parties bring annulment proceedings and request a stay of enforcement of awards on the basis of Article 52 of the ICSID Convention in cases brought under the ICSID. For instance, the annulment proceedings in CMS $v$. Argentina took 2 years; ${ }^{22}$ those in Continental v. Argentina 2 years and 8 months; ${ }^{23}$ and those in Sempra v. Argentina 2 years and 4 months. ${ }^{24}$ Accordingly, on average, annulment proceedings have lasted two years and four months. If one adds the 120 days parties have to file the annulment application, this de facto extension of suspension is roughly three years. ${ }^{25}$

Sykes and likeminded scholars thus need to respond to the argument of investors that suspension of compensation already exists in a de facto way and that, in any case, suspension should not be available, broadly speaking, when the award ordering the compensation is rendered years after the end of the economic crisis.

\section{Sykes' Grounds for the Incorporation of Compensation in the Event of Successful Invocation of Emergency Clauses}

While Sykes makes a strong case in explaining why a certain degree of compensation deals with the issues of moral hazard and the use of optimal policy instruments, it is regrettable that he left to others the task of fully arguing why this approach is enshrined in treaty texts such as Article XI of the United States-Argentina BIT, as opposed to only law-and-economics reasoning. Sykes states:

Only if a compensation requirement would itself "preclude" a "necessary" measure does the text seem to rule out compensation. It is difficult to imagine why a requirement of compensation deferred until such time as the exigent circumstances abate and the nation has resources to compensate, and appropriately limited in magnitude, would be preclusive. ${ }^{26}$

19 The proceedings in CMS v Argentina started on July 26, 2001, and the award was rendered on May 12, 2005.

20 The proceedings in Total v. Argentina began on October 12, 2003, and the decision on liability was issued on December 27, 2010.

21 The proceedings in Continental v. Argentina commenced on January 17, 2003, and the tribunal handed down its award on September 5,2008 .

22 The annulment proceedings in CMS v. Argentina started on September 8, 2005, and ended on Sept 25, 2007.

23 The annulment proceedings in Continental v. Argentina began on January 2, 2009, and were completed on September 16, 2011.

24 The annulment proceedings in Sempra v. Argentina commenced on January 25, 2008, and finished on June 29, 2010.

25 Apparently, the analysis of the suspension of compensation should be made on the basis of the average of both the length of arbitration and annulment proceedings. There is a jurisdictional issue that prevents from adding these two averages. Only the tribunal, not the ICSID ad hoc annulment committee, has jurisdiction to defer payment. The latter cannot make this decision on its own. Thus, adding the two averages is information that is of no value to any committee.

${ }^{26}$ Sykes, supra note 1 , at 321 . 
Sykes suggests that compensation would not be owed when it precluded a necessary measure. The argument refers to $a$ measure and $a$ compensation, namely specific cases, and one assumes that Sykes refers to cases involving more significant investments because compensation for small investments would not likely be precluded. Going further, the argument presupposes that States would be in a position to estimate the level of compensation required by each potential measure for each major investor and determine if any of this potential compensation is of such level to preclude the adoption of a measure necessary to address the emergency. The argument would continue: if the compensation was not prohibitive, the host State could afford it and therefore the measure affecting the investor would be adopted and indemnity to the investor owed. In sum, if compensation could be afforded ex ante, it could be paid ex post.

This line of argument presupposes that host States have the information to make this calculation with accuracy at the time of an economic crisis. This is highly unlikely. It is the investor who is better placed to know the extent of adverse effects on its investment. In fact, measures would be adopted only because they were necessary to address a crisis, not because host States knew in advance the extent of potential compensation due to particular, important investors and determined that it was not enough to preclude the adoption of the measure. ${ }^{27}$ States negotiated BITs, and it is improbable that they would include emergency clauses that presuppose the exercise of judgment on the basis of information they will not fully possess, to be assessed at a time in which all available resources should be devoted to mitigating or stopping the economic collapse, not to performing uncertain financial calculations regarding potential impacts on investors.

But even if the level of compensation could be estimated ex ante, and could be afforded, this chain of analysis does not necessarily lead to the creation of an obligation. It is one thing when a host State can afford to pay potential compensation, and quite another when the State has the obligation to pay it. Much more is required. The argument in the above quote in support of limited compensation needs to be rooted in an interpretation of the emergency clause in light of the Vienna Convention on the Law of Treaties, ${ }^{28}$ which Sykes does not address.

Moreover, the argument should respond to the fact that no subsequent practice by States, in particular the United States, has taken steps to introduce compensation within the text of emergency clauses in response to the case law. The NAFTA experience shows that, when States are unsatisfied with the evolution of the case law rendered by investor-State tribunals under an investment treaty, they agree on an interpretation that seeks to correct or adjust the undesired jurisprudence. ${ }^{29}$ Nothing of this sort has taken place. Furthermore, the U.S. 2012 model, which could have reacted to the case law, did not introduce compensation of any sort as a model for an emergency clause. ${ }^{30}$

\section{How to Mitigate the Strictures of the Zero Compensation Effect of Emergency Clauses? A Proposal}

The challenge that Sykes and other likeminded scholars face is that the case law on emergency clauses seems to have been settled, and hope seems limited for a change in the direction they advocate. An alternative for those unsatisfied with the case law is to recommend mechanisms that achieve a more balanced allocation

\footnotetext{
${ }^{27}$ Not to mention that there are other factors to be considered: the probabilities of litigation and of investors' success in their claims.

28 See Vienna Convention on the Law of Treaties, 1155 UNTS 331, May 23, 1969.

29 See North American Free Trade Agreement Free Trade Commission, Notes of Interpretation of Certain Chapter 11 Provisions (July 31 , 2001).

30 See 2012 U.S. Model Bilateral Investment Treaty, art. 18; and Michael D. Nolan \& Frederic G. Sourgens, The Limits of Discretion? Self-Judging Emergency Clauses in Bilateral Investment Agreements, Y.B. INT'L INV. L. \& POL'Y 363 (2010 - 2011).
} 
of risks between investors and States during economic collapses within the framework of the existing case law.

Arbitration tribunals have the last word regarding the length of the existence of the need for the application of the BIT necessity clause and can use it to control the impact of the successful invocation of the clause. The $L G \otimes E$ tribunal took this approach. Although the $L G \& E$ tribunal declared that the crisis met the requirements of Article XI and that no compensation was due to the investor during its duration, ${ }^{31}$ the tribunal significantly narrowed the length of the necessity when calculating the damages due by Argentina to LG\&E, in comparison with what the previous tribunal had determined in the CMS case. ${ }^{32}$ Full compensation was calculated from the date the LG\&E tribunal declared that the state of necessity had ceased to exist and Argentina should have started meeting its obligations to the investor, which it had not.

The definition of the length of the crisis is also important for the sharing of risks in another way: investors might be affected not by a single measure but by a set of measures adopted at different times. A narrow definition of the length of an economic collapse catches some measures and States would not have to pay compensation on account of them, while the later-in-time measures would fall outside of the crisis, and investors would have to be fully compensated in respect of these latter measures. ${ }^{33}$

A tribunal's decision regarding the length of the crisis is an important tool to allocate risks between investors and host States when the emergency clause is successfully invoked. By virtue of the operation of the clause, setting the dates of the crisis at the shortest length possible allows tribunals to alleviate the burden of the risks borne by foreign investors since, once the crisis is considered finished, full compensation is due to them and the risks are shifted to host States, even if their economic situation may not be totally normal.

31 See LG\&E Energy Copr. v. The Argentine Republic, Decision on Liability, ICSID Case No. ARB/02/1, para. 260 (Oct. 3, 2006) 46 ILM 40 (2007).

32 The LG\&E tribunal found the duration of the Argentine crisis to be much shorter than did the CMS tribunal. For the former, the crisis ran from December 1, 2001 until April 26, 2003, while for the latter, it ran from August 17, 2000 to some time at the end of 2004 or beginning of 2005. See $\underline{i d}$., at paras. 226-29; CMS Gas Transmission Company v. The Argentine Republic, ICSID Case No. ARB/01/8, Award, paras. 250, 441 (May 12, 2005), 14 ICSID Rep. 158.

33 See Continental Casualty v. Argentine Republic, Award, ICSID Case No. ARB/03/9, paras. 159 \& 220 (Sep. 5, 2008). 